The International Journal of

Urologic History $\subset$

www.ijuh.org

\title{
Rabbit Uroscopy and the Virgin Mary with Christ Child
}

\author{
Casey K. Ng*, E. Darracot Vaughan, Erich Meyerhoff \\ From the Department of Urology (CKN, EDV, EM), Weil Cornell Medical College, New York, New York \\ ${ }^{*}$ Correspondence: Southern California Permanente Medical Group, 13652 Cantara Street, Panorama City, California; e-mail: \\ caseyng@gmail.com
}

Introduction: The depiction of a rabbit with a urinary matula on the same page with the Virgin Mary and the Christ child in a medieval text, the Book of Hours, has raised interests among art and medical historians. We will describe the complex interplay between the rabbit, the matula, and the Virgin Mary.

Sources: We studied the original illuminated texts from the medieval (ca. 1475) Book of Hours archived in the Morgan Library, New York. We reviewed articles and historical publications from art history and medical literature.

Results: The Book of Hours was composed for use by lay people who wished to incorporate elements of monasticism into their devotional life. There was often an amalgamation of religious and secular themes within these illustrated texts. The use of uroscopy to diagnose ailments was prevalent and popular during the Middle Ages and the depiction of a matula was not uncommon in medieval manuscripts. As a result, the urine flask came to be identified with and used as a symbol of the physician, much like the caduceus is today. From the fourth century to modernity, the rabbit has been an averter of evil and bringer of good luck. Rabbits functioned as motifs in many medieval manuscripts. The physician rabbit in the Book of Hours depicted charity, healing, and scholarship.

Conclusions: The bespectacled rabbit holding a 'matula' is utilized in this Christian religious text as a symbol of the healing properties and resurrection attributed to Jesus, potentially contributing to the reader's religious experience.

Keywords: matula; uroscopy; Book of Hours, medieval medical history

$\mathrm{M}$ edieval prayer traditions included breviaries, psalters, and devotionals for daily life known as a Book of Hours. These highly personalized texts ranged in length and cost, and were prized by some of the 15th century's richest patrons who could commission a Book of Hours to be hand painted or 'illuminated', with religious portraits, depictions of daily life, symbolism, and family heraldry. Before the invention of mechanical printing, books were handmade objects treasured as works of art. Scribes copied the texts from an established edition. Then, artists might have embellished them with illustrations, decorated initials, and ornaments in the margins.(1)

One such Book of Hours from late 15th century France, now in the collection of Medieval Manuscripts at New York's Morgan Library, was illuminated by Barthelemy d'Eyck (died ca. 1476), painter to King René d'Anjou, and Enguerrand Quarton (ca. 1410ca. 1466). The book contains, among its 400 pages, a painted image of the "Virgin Mary with Christ Child". A closer inspection of the page margins, where artists often placed additional and allegorical drawings, is a rabbit, holding up for an inspection, a flask used to examine urine, known as a 'matula'. Uroscopy has played a role in medicine for centuries and the uroscopic evaluation of urine has been noted in Galenic texts and as part of the cover art of the Journal of Urology. The significance of a rabbit holding a matula in a 15th century devotional text, however, is unknown and what inspired the artists who illuminated the text has not been previously evaluated. We researched the history of the manuscript, its art, and the potential importance of 'rabbit uroscopy' in medieval Europe and contend that the rabbit enhances the religious narrative of the manuscript, thereby enriching the viewer's devotional experience (Figure 1).

\section{SOURCES}

The Book of Hours was originally commissioned by an unknown patron about 1440-1450 in Provence, France who hired the then famous illuminators of the TournaiGhent School, Barthélemy d'Eyck and Enguerrand Quarton, to personalize the text. Centuries later, the 
Book of Hours was sold to the 4th Earl of Ashburnham in 1849 and changed hands over the decades until it was purchased in 1909 by the famed American banker and bibliophile J. P. Morgan (1867-1943) who had extensive holdings in medieval art and manuscripts, all of which are now archived in the Morgan Library \& Museum, New York, NY, where it received its formal curatorial designation of MS M. 358. We also used curatorial notes from the Morgan Library, personal communications from historians, and secondary sources as cited.

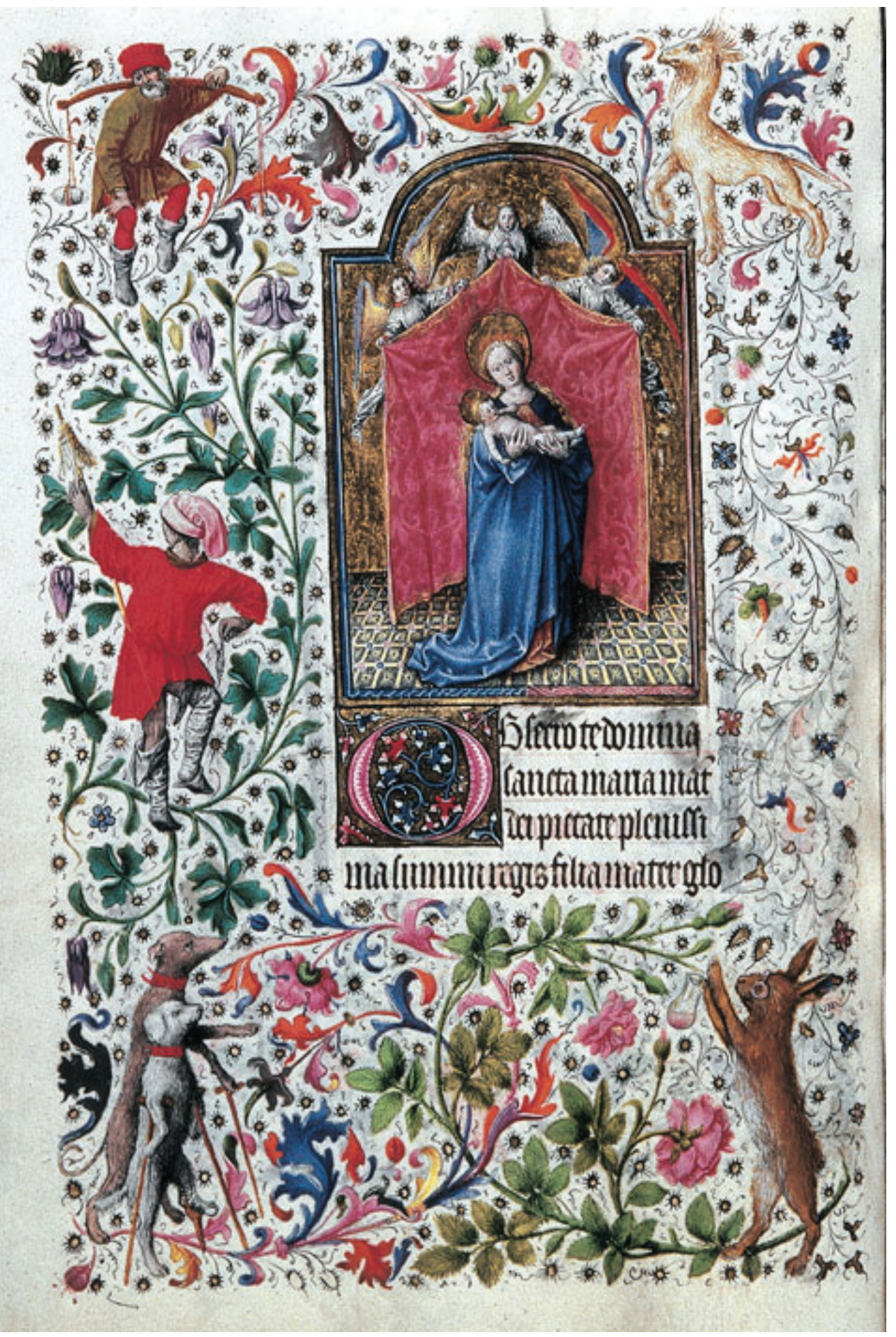

Figure 1. "Virgin Mary with the Christ Child", Book of Hours (MS M.358 fol. 20v, ca. 1440-50) probably illuminated by Barthélemy d'Eyck (d. ca. 1476). (Courtesy Morgan Library \& Museum, New York) 


\section{RESULTS AND DISCUSSION}

\section{The Book of Hours (MS M. 358)}

The manuscript measures $93 / 4 \times 63 / 4$ inches, is written on 15 th century vellum, and has been bound in red velvet since 1910 . The book is only partially illuminated and some pages are in various stages of incompletion. Some blank pages contain instructions to the illustrators which were not carried out. Still, the book contains 24 pages with so-called 'calendar' medallions depicting a representative activity of a month and its corresponding zodiac sign. The decoration about the text is of the highest quality, with brilliant clear colors across the spectrum in naturalistic backgrounds. There are also 10 illustrations and miniatures, including one of John the Baptist, Saint Mark, and the evangelists, and pages dedicated to prayers for the Penitential Psalms, to the Trinity, and a Mass for the Dead. Pages 20v-28v are devoted to prayers to the Virgin Mary entitled "Obsecro te" ("I beseech thee") and "O intemerata" ("Oh, immaculate one"). The miniature of the Virgin Mary and the illuminated page devoted to her form the basis of our study and which is generally credited to d'Eyck .

\section{Virgin Mary and Jesus}

The back of the 20th vellum of the Book of Hours depicts a miniature of the Virgin Mary behind whom are three angels holding up a curtain. Held in Mary's arms is the Christ Child. This specific page stood apart from other pages within the book for its details and original design. Unlike others in the book, images on this page were not transcribed from the previous page suggesting that careful attention was paid here.

When first viewing the Virgin Mary and Christ Child manuscript, one is drawn to the vibrant colors on this gilded manuscript. The Virgin Mary with Christ Child is surrounded by elaborate floral patterns, intertwined with various figures bordering on the edges. The figures within the arch frame are surrounded by a velvet drape held by three angels. Morgan Library notes suggest that a similar motif is seen in tomb bas-reliefs of 14th century Tournai strongly suggesting the artists origins. Though still influenced by gothic style, one could see the artists' attempt at creating depth and perspectives using the tiles on the floor. Influences from the Italian Renaissance are also seen in this manuscript; instead of being highly stylized, the figures' contoured bodies create a sculptural presence. Outside of the arch, the upper margin depicts a man carrying two objects, possibly stones, using a yoke balanced on shoulders and a hybrid animal facing him. In the left margin, a figure using a distaff and spindle is facing away. The bottom margin contains two dogs walking on crutches, one with a

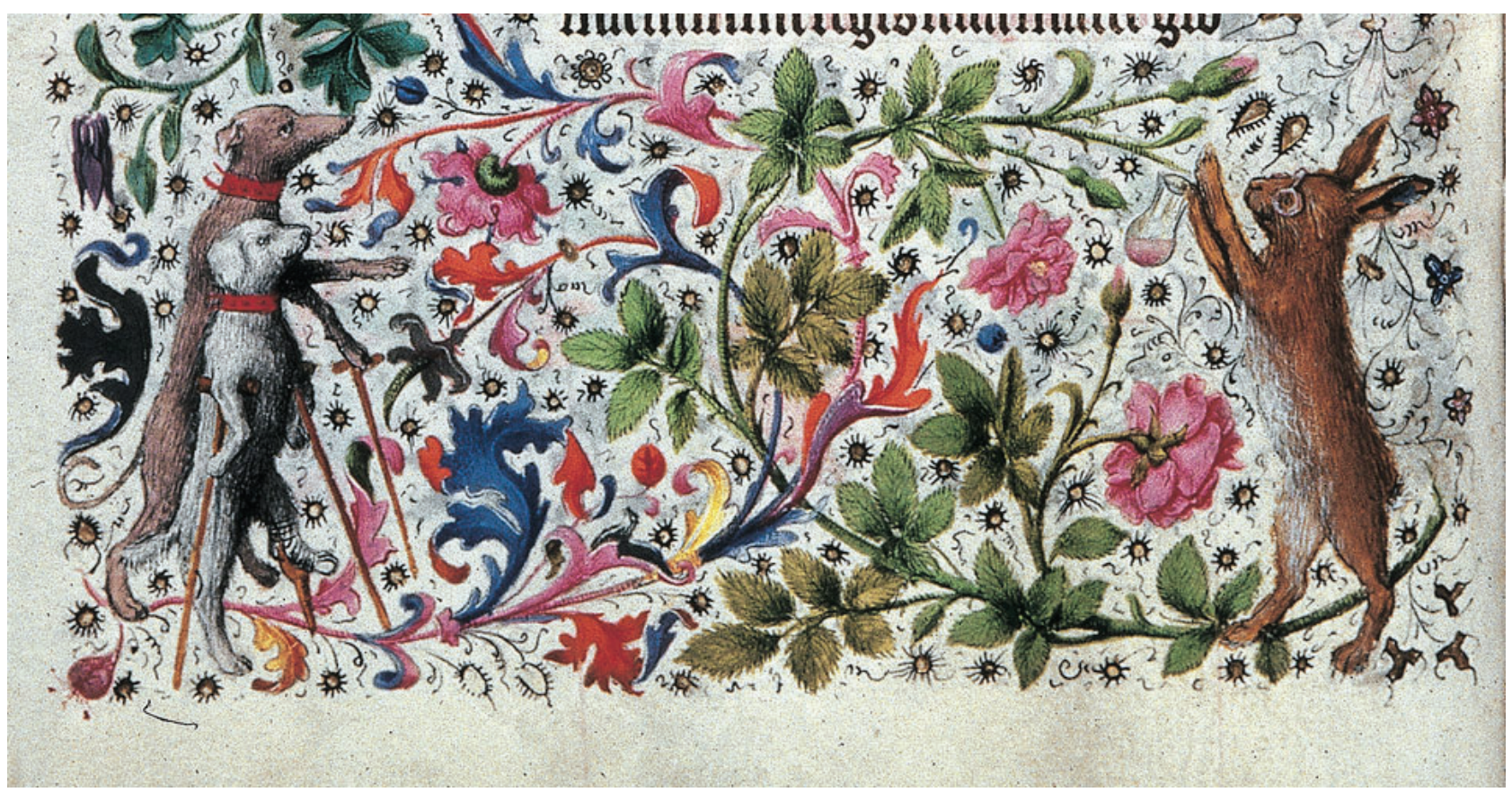

Figure 2. Enlarged lower margin of Figure 1 showing two injured dogs, now on crutches, walking towards the rabbit, wearing spectacles, and inspecting a 'matula', or a glass flask used to perform uroscopy. 
bandaged paw approaching a rabbit wearing eyeglasses. The rabbit is standing on hind legs while holding up a 'matula', a flask that held the urine for examination (Figure 2) and intended by the artist to be performing that role. (2) Unlike the hybrid animal in the top margin, the dogs and the rabbit are anthropomorphized. Not only do they stand as bipeds, these animals are using distinctly human instruments.

Depictions of the Virgin and Child were among the most popular images for private devotion, and they frequently emphasized the tender relationship between a mother and her child. Images included on the page margins assisted in these religious activities by creating tangible devotional objects. $(3,4)$

The corresponding text for this manuscript reflects such devotion:

"I beseech you, Mary, holy lady, mother of God, most full of piety, daughter of the greatest king, most glorious mother, mother of orphans, consolation of the desolate, the way for those who stray, salvation for those who hope in you, virgin before giving birth, virgin while giving birth, virgin after giving birth, fountain of pity, fountain of salvation and grace, fountain of piety and joy...and through that holy, great compassion and that most bitter sorrow in your heart that you had when you saw your Son, Our Lord Jesus Jesus, nude and lifted up on the cross, hanging, crucified, wounded, thirsty but served gall and vinegar and you heard him cry 'Eli' and you saw him dying ...Come and hasten to my and counsel, in all my prayers and requests, in all my difficulties and needs, and in all those things that I will do, that I will say, that I will think, in every day, night, hour and moment of my life...."(5)

\section{The Rabbit and Uroscopy}

As early as 4000 BC, Sumerian and Babylonian physicians had inspected urine for diagnosing disease. Hippocrates used uroscopy in conjunction with a thorough physical exam, including inspection, palpation and auscultation to assist in the diagnosis.(6) Over the next 1000 years, the use of uroscopy became more prominent. By the Middle Ages, the use of uroscopy alone for diagnosis was the norm. The practice was so popular that the matula became the symbol of a physician, much like the caduceus of today.' One of the most influential uroscopists at the time, Gilles de Corbeil, distinguished twenty different colors of urine from which he drew conclusions. The urinal itself was divided into thirds; he considered it significant where the different colors or contents of the urine appeared in the flask because he believed that each region of the flask corresponded to a part of the body. $(7,8)$

The bespectacled rabbit of 20v MS.358 performing uroscopy suggests the animal's anthropomorphic role as a physician. Glasses associated the wearer with an

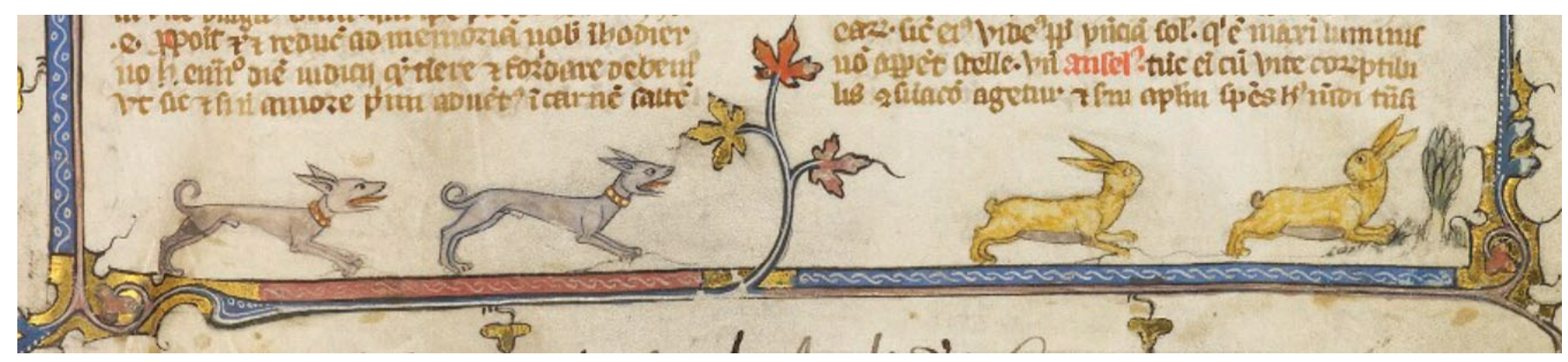

Figure 3. The more typical relationship of predator dog and prey rabbit, now reversed in the Morgan 35 Book of Hours (Source: The Bodleian Digital Archive. University of Oxford, Laud Misc. Fol 1r, p7 by Philippus, de Montecalerio, ca. 1336/44) 
academic life and an elite social class. Spectacles were regarded as a symbol of scholarship and educational superiority, even in an age when medicine was based on very little science.(9)

\section{Role Reversal}

The rabbit's role as a physician is further reinforced by the presence of the injured dogs. Dogs would usually chase and hunt for rabbits (Figure 3). Role reversal was a tool that had been used when depicting physicians. In the Smithfield Decretals (British Museum, Royal MS. $10 \mathrm{E} . \mathrm{N}$ ), the fox is depicted in multiple illustrations as a physician caring for a lion (Figure 4).(10) The traditional role of the hounds as pursuers of rabbits in the natural
Historically, the rabbit has also been a symbol of good luck. The rabbit's foot as an emblem of good fortune dates back to the fourth century. In a Latin medical text, Marcellus of Bordeaux proclaims "cut off the foot of a live rabbit and take airs from under its belly and let it go. Of those hairs or wool make a strong thread and with it bind the rabbit's foot to the body the patient and you will find a marvelous remedy."(11)

\section{CONCLUSIONS}

The artist's intent to bring a rabbit and uroscopy together illustrates a complex narrative within this manuscript. The amalgamation of religious and sectarian motifs is

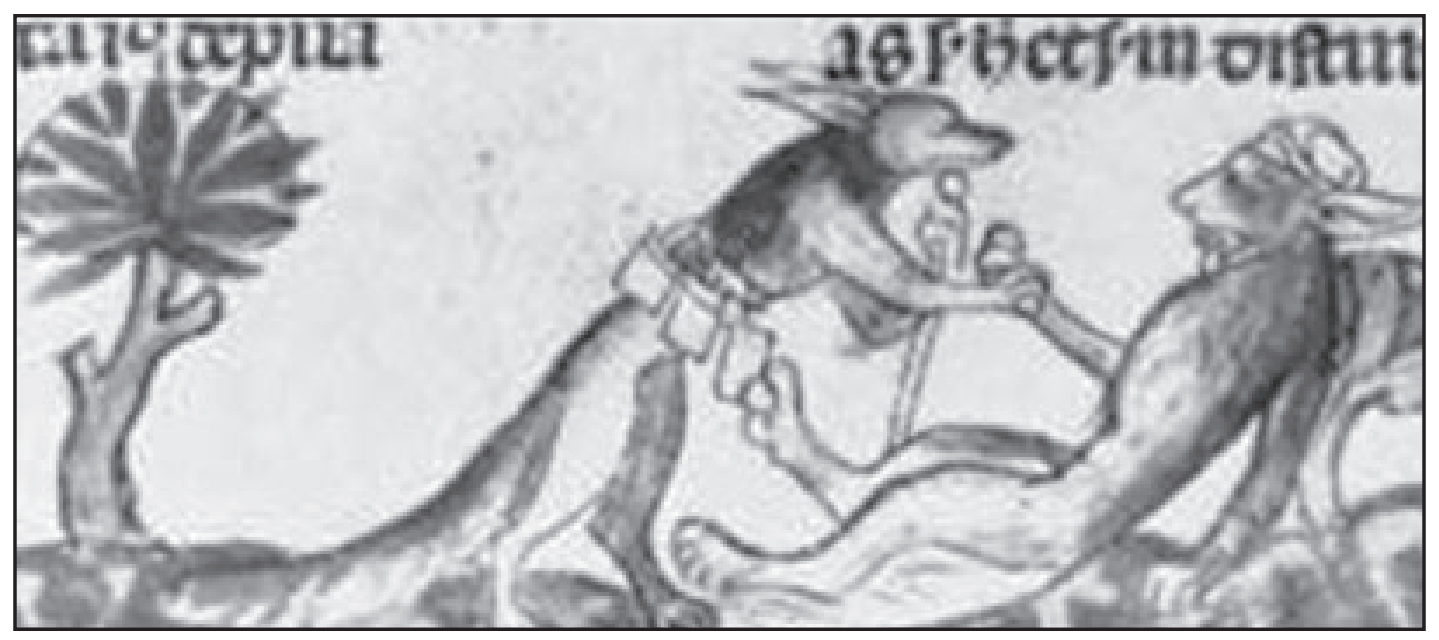

Figure 4. Allegorical role reversal, here showing fox as the physician, caring for the injured lion, like the physician rabbit in the Book of Hours, may depict a ministry whereby charity sees no distinction in friend or foe (Smithfield Decretals, Royal MS. 10 E. N, Courtesy British Museum)

world has here in the religious texts been reversed, and the dogs are now dependent upon the hare for their physical health. This inverted relationship reiterates the fact that physicians would take care of the sick and the ill even when the injured were their enemy. The illustrators used the rabbit and the dog to reveal a deeper message. The artist may be drawing a parallel between the rabbit as the physician and Jesus as a healer, caring for the sick even those who were his enemies.

\section{The Rabbit and Providence}

The use of animals to teach a moral may be taken directly from the Bible: "But ask the animals, and they will teach you, or the birds of the air, and they will tell you; or speak to the earth, and it will teach you, or let the fish of the sea inform you. Which of all these does not know that the hand of the Lord has done this? In his hand is the life of every creature and the breath of all mankind." (Job 12:7-10) consistent with the nature of the Book of Hours since it was a religious devotional text intended to be used in one's home on a daily basis. The matula is used to create an anthropomorphized rabbit physician. The interplay between the rabbit and the dogs expands on the idea that both physicians and Jesus took care of the sick and Enguerrand Quarton attempted to facilitate the concept of Jesus as a healer, potentially in an attempt to provide the reader with a more profound religious experience the weak even when they were adversaries. By depicting the rabbit in the Book of Hours, Barthelemy d'Eyck and Enguerrand Quarton attempted to facilitate the concept of Jesus as a healer, potentially in an attempt to provide the reader with a more profound religious experience. 


\section{REFERENCES}

1 Alexander, JG: Medieval Illuminators and Their Methods of Work. New Haven: Yale University Press, 1992.

2 William V, Curator, Medieval and Renaissance Manuscripts, The Pierpont Morgan Library. Personal Communication, February, 2007.

3 Van Os, HW: The Art of Devotion in the Late Middle Ages in Europe, 1300-1500. London: Merrell Holberton, 1994.

4 Department of Medieval Art and The Cloisters. "Private Devotion in Medieval Christianity", in: Timeline of Art History. New York: The Metropolitan Museum of Art, 2000.

5 Lindsay KC: Album Amicorum, (Eds) Stein, SA and George DM, Binghamton, State University of New York, 1990.

6 Harold S: Obstetrics and Gynecology: A History and Iconography - Iconographia Gyniatrica, 2nd Ed.. London: The Parthenon Publishing Group, 1994.

7 Connor, $\mathrm{H}$ : Medieval uroscopy and its representation on misericords - Part 1: Uroscopy. Clin Medicine 2001; 1: 507.

8 Haber, MH: Pisse Prophecy - A brief history of urinanalysis. Clin Lab Med 1988; 8: 415.

9 Flores, NC: Animals in the Middle Ages: A Book of Essays. New York: Garland Publishing, 1996.

10 Varty K: Reynard the Fox and the Smithfield Decretals, J Warburg Courtauld Inst 1963; 26: 347.

11. Wilson GP: Some Southern Folk Remedies, Georgia Review 1964; 18: 157. 